\title{
German Greens soften views on biotech as power edges closer
}

[MUNICH] Sensing a possible electoral victory in Germany's federal elections in September, which could result in a coalition government with the Social Democrat Party (SPD), the Greens have relaxed their critical approach to biotechnology and genetic engineering.

At the same time, German scientists are reacting cautiously to reports that, if such a coalition were to come to power, the Greens might choose the science ministry as one of the three ministries they would run (the other two being the foreign and the environment ministries).

At the Greens' annual conference, held in Magdeburg earlier this month, a large majority of delegates voted in favour of a motion supporting genetic engineering in drug design and diagnostics, as well as basic research. They agreed to add this so-called Gentechnikbeschluß to the party's election programme, but remain opposed to the use of genetic engineering in agriculture.

According to the news magazine der Spiegel, Gerhard Schröder, the SPD candidate for chancellor, is already considering Krista Sager as possible research minister in a coalition cabinet. Sager, who is 44 , is science minister in the Land (state) of Hamburg. She is both the first woman and the first Green to head a science ministry in Germany.

Many scientists and industry lobbyists are worried about such a prospect, given the Greens' fundamentalist grassroots. "We are not panicking, but if the Greens expect us to give up what we have achieved, for example in the Human Genome Project, they will face bitter resistance from scientists," says Detlev Ganten, head of the Max-Delbrück Centre for Molecular Medicine in Berlin.

Nevertheless Ganten, who is also president of the Helmholtz Society, the umbrella organization of Germany's national research centres, admits the Greens have abandoned many of their extreme positions, and believes they will reject more if they take on government responsibility. He describes Sager as "pragmatic, open-minded and competent".

Furthermore, politicians from either side insist that no definite decisions about ministerial positions will be made before the election. If an SPD-Green coalition is formed, Sager will have to compete with Social Democrat rivals.

In its effort to project a modernized image, the SPD has enthusiastically taken up the cause of research and technology, and in its election programme promises to double the current DM15 billion (US\$8 billion) annual federal budget for education,

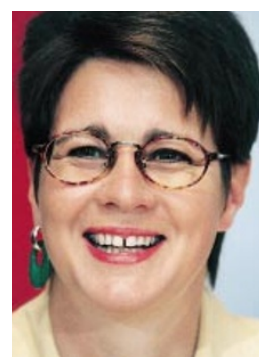

Sager: could be next research minister. research and technology. For their part the Greens, criticizing the promise as unrealistic, have proposed a comparatively modest increase of DM2 billion.

Wolf-Michael Catenhusen, the SPD spokesman on research, and another possible candidate as research minister, says that unresolved conflicts within the Greens about topics including the whole range of gene technology, disqualify them from taking responsibility for research and technology policy. Despite the Gentechnikbeschluß, some Greens still want all biotechnological products and methods banned.

But Manuel Kiper, spokesman for the Greens' parliamentary group on research policy, argues that his party's ideas on research - such as its 'soft' approach to biotechnology - are in line with German public opinion.

In addition to their traditional demand to abandon nuclear energy, the Greens want to end Germany's contribution to various major international research projects, including the proposed fusion reactor ITER and the international space station (and manned space exploration in general).

Kiper stresses, however, that his party accepts the general importance of science and technology, and says the Greens should no longer be described as a 'Stone Age party'. "We certainly don't continue to cling to Green positions that were formed 12 years ago," he says.

Under the framework of sustainable development and social responsibility, the main pillars of the Greens' science policy are environmental research, information technology and research on transport.

In contrast to the views of the present research minister, Jürgen Rüttgers, and to mainstream political thinking, the Greens say basic research should be given higher priority than applied research. This surprising stance first became apparent in the party's position paper on science policy, published more than a year ago (see Nature 385, 382; 1997). The paper criticized Rüttgers for "overemphasizing industrial research aimed at short-term economic gain" and called for the re-establishment of basic research as the main priority.

QuirinSchiermeier Clinton told to speed up plutonium disposal

[WASHINGTON] A high-powered Washington panel has sharply rebuked the Clinton administration for dragging its feet on the disposal of plutonium from surplus US nuclear warheads.

The Center for Strategic and International Studies says that the administration has failed to get the disposal programme under way at home, and to win agreement for similar efforts in Russia.

A report from the centre calls for a formal agreement between the United States and Russia to ensure that plutonium 'pits' - or cores - from thousands of nuclear warheads rendered surplus by arms-control agreements are processed into safer shapes, and then disposed of.

But the panel of senior scientists, engineers and former diplomats who drew up the report are especially angry with the US administration for failing to make disposal a higher priority. "At the moment, there is more leadership in Russia on this than there is in the United States," says John Taylor, a consultant at the Electric Power Research Institute in California, and chairman of the panel.

Senator Pete Domenici (Republican, New
Mexico), who chairs the committee allocating the disposal programme's budget at the Department of Energy, co-chaired the panel and endorses its conclusions.

"This issue has not received the appropriate level of interest in the Clinton administration," says Domenici, who warns that Russian weapons components could fall into the hands of terrorists if inaction continues.

The report says that both the United States and Russia should press ahead immediately with converting the pits into less dangerously shaped blocks of plutonium, in advance of disposing of the plutonium itself.

The United States is building a prototype facility to do this at the Los Alamos National Laboratory in New Mexico, using a dry process based on hydrogen gas. But a full-scale facility is not due to come on line until 2005.

The report attributes the overall slow progress to a lack of commitment from senior administration officials. "There presently is little or no serious leadership within the US government... to move the programme forward," it says. Colin Macilwain 